\title{
Potential of watermelon (Citrullus lanatus) to maintain oxidative stability of rooster semen for artificial insemination
}

\author{
Olatunji Abubakar Jimoh ${ }^{1 *}$, Micheal Olawale Akinola, Bolaji Fatai Oyeyemi \\ Wahab Adekunle Oyeyemi ${ }^{3}$, Simeon Olugbenga Ayodele ${ }^{1}$, \\ Idowu Samuel Omoniyi and Hafsat Ololade Okin-Aminu ${ }^{4}$ \\ ${ }^{1}$ Department of Agricultural Technology, The Federal Polytechnic Ado-Ekiti, Ekiti State 360101, Nigeria \\ ${ }^{2}$ Molecular Biology Group, Department of Science Technology, The Federal Polytechnic Ado-Ekiti, Ekiti \\ State 360101, Nigeria \\ ${ }^{3}$ Department of Physiology, Igbenedion University, Okada, Edo State 302110, Nigeria \\ ${ }^{4}$ Animal Science Department, Ahmadu Bello University, Zaria, Kaduna State 810241, Nigeria
}

Received: Jul 12, 2020

Revised: Sep 19, 2020

Accepted: Nov 19, 2020

*Corresponding author Olatunji Abubakar Jimoh

Department of Agricultural Technology, The Federal Polytechnic Ado-Ekiti,

Ekiti State 360101, Nigeria.

Tel: +234-806-6058134

E-mail: abubakarjimoh2011@gmail.com

Copyright $(\subset) 2021$ Korean Society of Animal Sciences and Technology. This is an Open Access article distributed under the terms of the Creative Commons Attribution Non-Commercial License (http:// creativecommons.org/licenses/by$\mathrm{nc} / 4.0 /$ ) which permits unrestricted non-commercial use, distribution, and reproduction in any medium, provided the original work is properly cited.

ORCID

Olatunji Abubakar Jimoh

https://orcid.org/0000-0001-8204-5816 Micheal Olawale Akinola

https://orcid.org/0000-0002-2744-3448

Bolaji Fatai Oyeyemi

https://orcid.org/0000-0001-5564-6165

Wahab Adekunle Oyeyemi

https://orcid.org/0000-0001-9620-1234

Simeon Olugbenga Ayodele

https://orcid.org/0000-0003-2913-6123

Idowu Samuel Omoniyi

https://orcid.org/0000-0002-2412-7597

Hafsat Ololade Okin-Aminu

https://orcid.org/0000-0001-7738-811X

\section{Abstract}

Fruits with antioxidant enrichment can be an economically affordable supplement for mitigating oxidative damage prone spermatozoa membrane pathologies. Computer-assisted sperm analyzer and oxidative status were utilized to evaluate the impact of watermelon (Citrullus lanatus) fortification of dextrose saline as diluent for rooster semen and fertility response of hens inseminated. Watermelon juice and dextrose saline were used to formulate diluent of 7 treatments consisting of unextended semen (positive control), 10\%, 20\%, 30\%, 40\%, 50\% and only dextrose saline (negative control) designated as Treatments 1-7. Pooled semen was obtained from fertile roosters and equilibrated with diluents at ratio 1:2 in the various treatments and were evaluated using computer software coupled microscope and seminal oxidative status assay. 168 laying hens randomly divided into 7 treatment of 8 replicates and 3 hen per replicate. Hen were everted, and semen $\left(2 \times 10^{8}\right.$ Spermatozoa) deposited intra-vagina and eggs collected over 8 weeks to assess fertility and hatchability of eggs laid. The result obtained revealed that watermelon-dextrose saline rooster semen diluent enhanced progressive motility, sperm kinetics and lowered non-progressive motility in T2-T6 compared to $\mathrm{T7}$ over the 3 hours of evaluation. Watermelon addition to rooster semen diluent enhance the antioxidant capacity of rooster semen and lowered lipid peroxide generation. The percentage fertility was highest in T3 $(81.01 \%)$ and T4 $(81.24 \%)$ with lowest value obtained in T7 $(73.46 \%)$. The hatchability of eggs set of hens inseminated with undiluted semen $(71.46 \%)$ was lower than values for hens inseminated with watermelon inclusive extended semen $(75.71 \%-80.39 \%)$. The optimal inclusion of $30 \%-40 \%$ watermelon in dextrose saline diluent enhance rooster semen kinetics, seminal oxidative stability and egg fertility.

Keywords: Rooster semen, Dextrose saline, Hatchability, Semen diluent, Sperm kinetics, Watermelon 
Competing interests

No potential conflict of interest relevant to this article was reported.

Funding sources

The research outcome presented in this article was funded by TETFUND 2018 institution based research intervention of the Nigeria government.

Acknowledgements

Not applicable.

Availability of data and material Upon reasonable request, the datasets of this study can be available from the corresponding author.

\section{Authors' contributions}

Conceptualization: Jimoh OA, Akinola MO.

Data curation: Jimoh OA.

Formal analysis: Oyeyemi BF, Oyeyemi WA.

Methodology: Jimoh OA, Oyeyemi WA,

Ayodele SO, Omoniyi IS.

Software: Oyeyemi WA.

Validation: Jimoh OA, Oyeyemi BF, Ayodele

SO, Omoniyi IS.

Investigation: Jimoh OA, Okin-Aminu $\mathrm{HO}$

Writing - original draft: Jimoh OA, OkinAminu $\mathrm{HO}$.

Writing - review \& editing: Jimoh OA, Akinola MO, Oyeyemi BF, Oyeyemi WA, Ayodele $\mathrm{SO}$, Omoniyi IS, Okin-Aminu $\mathrm{HO}$.

Ethics approval and consent to participate This research was undertaken with approval from institutional ethics committee of the Federal Polytechnic, Ado-Ekiti with IACUC approval no: FPA/EC/19/0062. The institutional and national standards for the care and use of animals for research in the Research Policy Handbook of the Federal Polytechnic, Ado-Ekiti were followed and appropriate measures were taken to minimize pain or discomfort on the animals and it was in accordance with $\mathrm{NIH}$ guide for the care and use of laboratory animals.

\section{INTRODUCTION}

The genetic improvement of offspring quality and potential for the propagation of hybrids germplasm by assisted semen delivery into the female reproductive tract is achievable through artificial insemination (AI). In vitro, spermatozoa motility of fresh semen decreases within hour of collection and consequently reduces fertility potential [1]. The importance of extender in poultry is to increase volume and facilitate prolonged handling, maintaining good sperm motility and viability through inhibition of pathways detrimental to semen. During semen handling and storage, there is often the problem of the formation of lipid peroxides causing impaired spermatozoa plasma membrane, which culminate into decrease in semen motility [2]. Seminal plasma possesses an antioxidant system to mitigate the consequences of reactive oxygen species (ROS) accumulation; this seems to protect sperm cells. Unfortunately, this protective capacity is limited in spermatozoa compared with somatic cells $[3,4]$.

There are reports that suggests that herbs and fruits with antioxidant enrichment protect cells by mitigating oxidative damage [5-7]. Bayemi et al. [8] reported that fruits based extenders performed better in improving sperm motility than egg yolk extenders. Balogun and Jimoh [9] developed garlic extracts as a supplement in rooster semen diluent with appreciable success, but this requires high standardization and techniques which limits its use by local farmers. Eggs are relatively more expensive than fruits, thus tropical fruits based extenders may be more economically effective in AI practise in farming households. Imminently, growing interests in a new generation of semen extenders based on the presence of natural products to minimize the risk of contamination through fruits containing natural antioxidants which are more acceptable than synthetic antioxidants [10].

Watermelon is a good source of lycopene and citrulline, it also contains large amounts of beta-carotene and Vitamin C [11]. The therapeutic effect of watermelon has been ascribed to its composition of a myriad of antioxidant compounds; chiefly citrulline and lycopene [12]. Water melon based diluents has shown great potential in rabbit semen extension and AI [13]. There is growing interests to utilize fruits and natural extracts as diluents and constituents of semen extender. This study attempt to harness the potentials of water melon fortification of dextrose saline on roosters semen extension.

\section{METHODS}

\section{Experimental animals and management}

This research was undertaken with approval from the institutional ethics committee with IACUC approval no:- FPA/EC/19/0062 and the National Institutes of Health guide for the care and use of Laboratory animals were followed, and appropriate measures were taken to minimize pain or discomfort on the animals.

Thirty five to forty weeks old breeder roosters (30) and breeder hens (168) were obtained from a reputable breeder farm were used for this study. Ripe water melon (Sugar baby variety) fruit was purchased, washed, peeled and the fruit pulp blended. Juice extractor (Mikachi model No 1706) was used to clarify the fruit juice and was designated as watermelon juice (WMJ) and kept frozen at $4^{\circ} \mathrm{C}$ in disposable $5 \mathrm{~mL}$ sterile sample bottles. Dextrose saline $(5 \%$ dextrose in $0.9 \%$ normal saline; Unique pharmaceuticals, Nig.) was procured for the study. The experimental design is an entirely randomized design, consisting of seven treatments, 8 replicates and three birds per replicate.

Prior to collection of the semen, 2 weeks training for 30 roosters was undertaken and semen were harvested twice weekly and ejaculates evaluated using in-vitro analysis. Semen collection was carried out according to the modified collection procedure outlined by Balogun et al. [14]. All 
roosters were assessed for fertility and only roosters of good fertility were used, care was taken to avoid any contamination of semen with faeces.

\section{Extension of semen with extenders and evaluation}

Seven (7) treatments consist of different diluent formulated. Treatment 1: undiluted semen (positive control), Treatment 2: dextrose saline $+10 \% \mathrm{WMJ}$ diluent, Treatment 3: dextrose saline $+20 \%$ WMJ diluent, Treatment 4: dextrose saline + 30\% WMJ diluent, Treatment 5: dextrose saline + 40\% WMJ diluent, Treatment 6: dextrose saline + 50\% WMJ diluent, Treatment 7: dextrose saline $+0 \% \mathrm{WMJ}$ diluent (negative control).

The pooled semen were allotted as described earlier and diluted with respective extender dose. Diluted samples at $1: 2$ (semen : diluents) was equilibrated by mixing gently and semen assessment took place immediately. Semen qualitative and oxidative assay were assessed for each treatment. The assessments were done hourly for 3 hours.

\section{Semen evaluation}

Extended semen according to treatments were evaluated for sperm kinetics using computer assisted sperm analyzer (SpermAnalyzeWin7 Xuzhon city, China, setting of CASA as in 5th WHO manual, 51 sperm tracks, evaluated magnification $\times 10$, image acquisition rate: number frames $/ \mathrm{s}$ 60); percentage motility, progressive motility, non- progressive motility, curvilinear velocity (um/s), average path velocity ( $\mathrm{um} / \mathrm{s})$, straight line velocity ( $\mathrm{um} / \mathrm{s})$, linearity, straightness, amplitude of lateral head (um), beat cross frequency $(\mathrm{Hz})$, wobble, While sperm concentration and livability using convention procedures. Sperm concentration (duplicates per sample) were determined using Neubauer haemocytometer (TH-100, HechtAssistant, Sondheim, Germany) and expressed as spermatozoa $\times$ $10^{8} / \mathrm{mL}$. Livability was done by placing a drop of semen on a glass slide, one drop of eosin-nigrosin stain added and mixed gently, then smeared on a slide, air-dried and viewed under the microscope at magnification of $\times 400$.

\section{Oxidative status assay}

The semen samples of all treatment obtained at zero and three hours were centrifuged and seminal fluid obtained was assayed for lipid peroxidation and total antioxidant activity using standard procedures as outlined by Jimoh et al. [6]. The assay for seminal lipid peroxidation involve the reaction mixture in a total volume of $3.0 \mathrm{~mL}$ contained $1.0 \mathrm{~mL}$ seminal plasma and $1.0 \mathrm{~mL}$ of trichloroacetic acid (TCA) (0.67\%). All the test tubes were placed in a boiling water bath for a period of $45 \mathrm{~min}$. The tubes were shifted to the ice bath and then centrifuged at $12,000 \mathrm{~g}$ for $10 \mathrm{~min}$. The amount of malondialdehyde (MDA) formed in each of the samples was assessed by measuring the optical density of the supernatant at 532nm [15].

Seminal total antioxidant capacity activities involve a reaction mixture containing $0.5 \mathrm{~mL}$ of a (10 mmol/L) Na-Benzoate, $0.2 \mathrm{~mL}$ of $\mathrm{H}_{2} \mathrm{O}_{2}(10 \mathrm{mmol} / \mathrm{L}), 0.49 \mathrm{~mL}$ of phosphate buffer $(100$ $\mathrm{mmol} / \mathrm{L}, \mathrm{pH}=7.4$ ) (prepared by mixing $19.5 \mathrm{~mL}$ of $\mathrm{KH}_{2} \mathrm{PO}_{4}(100 \mathrm{mmol} / \mathrm{L}$ ) with $80.5 \mathrm{~mL}$ of $\mathrm{Na}_{2} \mathrm{HPO}_{4}(100 \mathrm{mmol} / \mathrm{L})$, then adjusted the $\mathrm{pH}$ to 7.4 and $0.2 \mathrm{~mL}$ of Fe-ethylenediaminetetraacetate (EDTA) complex ( $2 \mathrm{mmol} / \mathrm{L}$ ) (prepared freshly by mixing equal volumes of EDTA ( $2 \mathrm{mmol} /$ $\mathrm{L})$, and ferrous ammonium sulfate $(2 \mathrm{mmol} / \mathrm{L})$, then left at $25^{\circ} \mathrm{C}$ for $60 \mathrm{~min}$. Ten microliters of the seminal plasma were added to the latter reactive mixture and were incubated at $37^{\circ} \mathrm{C}$ for $60 \mathrm{~min}$. Finally, $1 \mathrm{~mL}$ glacial acetic acid $(20 \mathrm{mmol} / \mathrm{L})$ and $1 \mathrm{~mL}$ thiobarbituric acid $(0.8 \% \mathrm{w} / \mathrm{v}$ in $100 \mathrm{~mL}$ of $50 \mathrm{mmol} / \mathrm{L} \mathrm{NaOH}$ ) were added, and the absorbance at $532 \mathrm{~nm}$ was measured spectrophotometrically after incubation at $100{ }^{\circ} \mathrm{C}$ for $10 \mathrm{~min}$. Total antioxidant capacity was calculated according to the following formula: 
$\mathrm{T}$ A capacity $(\mathrm{mmol} / \mathrm{L})=(\mathrm{CUA})(\mathrm{K}-\mathrm{A}) /(\mathrm{K}-\mathrm{UA})$

Where CUA (mmol/L); concentration of uric acid; K: absorbance of the control (K1 - K0); A: absorbance of the sample (A1 - A0); UA: absorbance of uric acid solution (UA1 - UA0) [16].

\section{Artificial insemination}

The hens were randomly divided into 7 treatments, each comprising of 8 replicates and 3 hens per replicate. The hen insemination took place immediately after the assessment of semen quality. Each hen was everted and semen deposited into the intra vagina of the hen through the use of tuberculin syringe in which tubular glass rod is attached to its mouth with the aid of rubber cork. The hens were inseminated twice weekly in the evening for eight weeks. And the insemination doses were $0.01 \mathrm{~mL}$ per hen $\left(2 \times 10^{8}\right.$ spermatozoa). Eggs were collected for 7 weeks after the first week of insemination.

\section{Egg fertility assessment}

Eggs were collected daily, stored and incubated weekly. Eggs were incubated in a reputable commercial hatchery. The fertility percentage ([fertile eggs / total eggs $] \times 100$ ) was determined by candling on the 18th day of incubation. Using the formulae below:

$$
\% \text { fertility }=\text { Fertile eggs } / \text { Total eggs set } \times 100
$$

At every 18th day of incubation, eggs were transferred from the setter to the hatcher (sections of the incubator) for the last 7 days were incubation and hatching took place. Hatching percentage was determined by hatching of fertile eggs about 21 days of incubation. Numbers of chicks hatched were counted and percentage hatchability calculated using the formular below:

$$
\begin{gathered}
\text { Hatchability of fertile eggs }(\%)=(\text { Hatched eggs } / \text { Fertile eggs }) \times 100 \\
\text { Hatchability of eggs set }(\%)=(\text { Hatched eggs } / \text { Total eggs }) \times 100
\end{gathered}
$$

\section{Statistical analysis}

The data obtained were subjected to descriptive statistics and one way analysis of variance of GLM procedure of IBM SPSS 25 at $p=0.05$. Differences in mean value were separated using New Duncan's multiple range test.

The statistical model is as follow:

$$
\text { Yijk }=\mu+\mathrm{Bi}+\text { eijk }
$$

Where Yijk represents the value of spermatozoa kinetics, oxidative stability and fertility measured in the ith diluted semen; $\mu$ is the overall mean for each character; $\mathrm{Bi}$ is the fixed effect of ith rooster semen diluted watermelon ( $\mathrm{i}=\mathrm{T} 1$ is undiluted semen (positive control), watermelon was incorporated into dextrose saline at $0 \%, 10 \%, 20 \%, 30 \%, 40 \%$, and 50\%); and eijk is the random residual effect.

\section{RESULTS}

\section{Semen quality of watermelon fortified rooster semen ab initio}

The semen quality of watermelon fortified rooster semen is shown in Table 1 . The semen motility and viability was statistically similar across the treatments. Progressive motility values was signifi- 
Table 1. Semen characteristics of watermelon extended rooster semen at 0 hour

\begin{tabular}{|c|c|c|c|c|c|c|c|}
\hline Parameters & T1 & T2 & T3 & T4 & T5 & T6 & $\mathrm{T7}$ \\
\hline Percentage motility (\%) & 93.30 & 90.43 & 90.38 & 89.79 & 90.40 & 90.11 & 92.18 \\
\hline Progressive motility (\%) & $55.05^{d}$ & $69.64^{\mathrm{c}}$ & $83.68^{\mathrm{a}}$ & $81.08^{\mathrm{ab}}$ & $84.55^{\mathrm{a}}$ & $83.55^{\mathrm{a}}$ & $72.57^{\mathrm{bc}}$ \\
\hline Non- progressive motility (\%) & $38.25^{\mathrm{a}}$ & $20.80^{\mathrm{b}}$ & $6.70^{\mathrm{c}}$ & $8.71^{\mathrm{c}}$ & $5.85^{\mathrm{c}}$ & $6.57^{\mathrm{c}}$ & $19.61^{b}$ \\
\hline Curvilinear velocity $(\mathrm{VCL})(\mu \mathrm{m} / \mathrm{s})$ & $15.00^{\mathrm{b}}$ & $21.45^{\mathrm{b}}$ & $27.29^{\mathrm{a}}$ & $28.94^{\mathrm{a}}$ & $28.32^{\mathrm{a}}$ & $28.22^{\mathrm{a}}$ & $22.43^{\mathrm{ab}}$ \\
\hline Average path velocity (VAP) $(\mu \mathrm{m} / \mathrm{s})$ & $5.74^{\mathrm{b}}$ & $19.45^{\mathrm{a}}$ & $19.40^{\mathrm{a}}$ & $20.25^{\mathrm{a}}$ & $19.70^{\mathrm{a}}$ & $19.72^{\mathrm{a}}$ & $22.46^{\mathrm{a}}$ \\
\hline Straight line velocity (VSL) $(\mu \mathrm{m} / \mathrm{s})$ & $7.30^{\mathrm{b}}$ & $9.72^{\mathrm{a}}$ & $8.04^{\mathrm{ab}}$ & $8.30^{\mathrm{a}}$ & $8.02^{\mathrm{ab}}$ & $8.09^{\mathrm{ab}}$ & $9.48^{\mathrm{a}}$ \\
\hline Linearity (\%) & $30.18^{b}$ & $52.90^{\mathrm{a}}$ & $53.30^{\mathrm{a}}$ & $52.71^{a}$ & $51.95^{\mathrm{a}}$ & $52.44^{a}$ & $54.40^{\mathrm{a}}$ \\
\hline Straightness (\%) & $46.38^{b}$ & $61.84^{\mathrm{a}}$ & $62.89^{a}$ & $61.96^{\mathrm{a}}$ & $61.46^{\mathrm{a}}$ & $61.87^{\mathrm{a}}$ & $63.93^{\mathrm{a}}$ \\
\hline Amplitude of lateral head (ALH) $(\mu \mathrm{m})$ & $0.76^{\mathrm{a}}$ & $0.42^{\mathrm{c}}$ & $0.50^{c}$ & $0.50^{c}$ & $0.48^{\mathrm{c}}$ & $0.49^{c}$ & $0.62^{\mathrm{b}}$ \\
\hline Beat cross frequency $(\mathrm{BCF})(\mathrm{Hz})$ & $4.48^{\mathrm{a}}$ & $3.77^{\mathrm{b}}$ & $4.35^{\mathrm{a}}$ & $4.70^{\mathrm{a}}$ & $4.68^{\mathrm{a}}$ & $4.58^{\mathrm{a}}$ & $5.00^{\mathrm{a}}$ \\
\hline Wobble (\%) & $64.44^{\mathrm{b}}$ & $70.78^{\mathrm{a}}$ & $54.33^{b}$ & $54.13^{\mathrm{b}}$ & $52.99^{b}$ & $53.57^{b}$ & $55.54^{b}$ \\
\hline Viability (\%) & 93.30 & 90.43 & 90.38 & 89.79 & 90.40 & 90.11 & 92.18 \\
\hline
\end{tabular}

${ }^{a-d}$ Means in the same row with different superscripts are significantly $(p<0.05)$ different.

Treatments are \% watermelon in dextrose saline diluents: T1 is undiluted semen (positive control); T2, $10 \% ; \mathrm{T} 3,20 \%$; T4, 30\%; $\mathrm{T} 5,40 \%$; $\mathrm{T} 6,50 \%$; $\mathrm{T7}, 0 \%$.

cantly $(p<0.05)$ highest in T3, T4, T5, and T6 semen groups, while values of T7 and T2 semen groups were not significantly $(p>0.05)$ different. The significantly $(p<0.05)$ lowest semen progressive motility was observed in T1. Non- progressive motility of semen in T1 was significantly $(p<0.05)$ highest. The significantly $(p<0.05)$ lowest semen non progressive motility was obtained in semen on T3, T4, T5, and T6. The average path velocity, linearity and straightness of diluted semen (T2-T7) were significantly $(p<0.05)$ higher than undiluted semen (T1). Amplitude of lateral head of semen was $(p<0.05)$ higher in undiluted semen than in the diluted semen group (T2-T7). Wobble of semen in T2 was the highest, T1, T3, T4, T5, T6, and T7 semen groups were lowest.

\section{Semen quality of watermelon extended rooster semen for 1 hour}

Semen quality of watermelon extended rooster semen for 1 hour is shown in Table 2. Progressive

Table 2. Semen characteristics of watermelon extended rooster semen at 1 hour

\begin{tabular}{lccccccc}
\hline \multicolumn{1}{c}{ Parameters } & T1 & T2 & T3 & T4 & T5 & T6 & T7 \\
\hline Percentage motility (\%) & $90.50^{\mathrm{abc}}$ & $91.16^{\mathrm{a}}$ & $90.73^{\mathrm{abc}}$ & $89.67^{\mathrm{bc}}$ & $89.78^{\mathrm{b}}$ & $91.01^{\mathrm{ab}}$ & $89.60^{\mathrm{c}}$ \\
Progressive motility (\%) & $83.99^{\mathrm{a}}$ & $80.87^{\mathrm{b}}$ & $84.45^{\mathrm{a}}$ & $83.84^{\mathrm{a}}$ & $83.65^{\mathrm{ab}}$ & $82.67^{\mathrm{ab}}$ & $82.19^{\mathrm{ab}}$ \\
Non- progressive motility $(\%)$ & $6.51^{\mathrm{b}}$ & $10.30^{\mathrm{a}}$ & $6.28^{\mathrm{b}}$ & $5.83^{\mathrm{b}}$ & $6.13^{\mathrm{b}}$ & $8.34^{\mathrm{ab}}$ & $7.42^{\mathrm{ab}}$ \\
Curvilinear velocity $(\mathrm{VCL})(\mu \mathrm{m} / \mathrm{s})$ & 18.25 & 17.82 & 17.82 & 17.15 & 18.15 & 18.34 & 16.73 \\
Average path velocity (VAP) $(\mu \mathrm{m} / \mathrm{s})$ & 9.79 & 10.23 & 9.69 & 9.25 & 9.71 & 10.07 & 9.32 \\
Straight line velocity (VSL) $(\mu \mathrm{m} / \mathrm{s})$ & $4.08^{\mathrm{ab}}$ & $4.44^{\mathrm{a}}$ & $4.06^{\mathrm{ab}}$ & $3.92^{\mathrm{b}}$ & $4.08^{\mathrm{ab}}$ & $4.31^{\mathrm{ab}}$ & $4.04^{\mathrm{ab}}$ \\
Linearity $(\%)$ & $22.33^{\mathrm{c}}$ & $24.89^{\mathrm{a}}$ & $22.79^{\mathrm{c}}$ & $22.87^{\mathrm{c}}$ & $22.49^{\mathrm{c}}$ & $23.98^{\mathrm{b}}$ & $24.18^{\mathrm{ab}}$ \\
Straightness (\%) & $41.65^{\mathrm{c}}$ & $43.34^{\mathrm{a}}$ & $41.90^{\mathrm{c}}$ & $42.38^{\mathrm{bc}}$ & $42.02^{\mathrm{bc}}$ & $42.79^{\mathrm{ab}}$ & $43.36^{\mathrm{a}}$ \\
Amplitude of lateral head $(\mathrm{ALH})(\mu \mathrm{m})$ & $0.49^{\mathrm{bc}}$ & $0.51^{\mathrm{ab}}$ & $0.48^{\mathrm{c}}$ & $0.50^{\mathrm{ab}}$ & $0.48^{\mathrm{c}}$ & $0.52^{\mathrm{a}}$ & $0.50^{\mathrm{ab}}$ \\
Beat cross frequency (BCF) (Hz) & $4.66^{\mathrm{a}}$ & $4.29^{\mathrm{ab}}$ & $4.51^{\mathrm{ab}}$ & $4.27^{\mathrm{ab}}$ & $4.67^{\mathrm{a}}$ & $4.57^{\mathrm{ab}}$ & $4.08^{\mathrm{b}}$ \\
Wobble (\%) & $53.59^{\mathrm{cd}}$ & $57.44^{\mathrm{a}}$ & $54.41^{\mathrm{cd}}$ & $53.96^{\mathrm{cd}}$ & $53.53^{\mathrm{d}}$ & $54.88^{\mathrm{bc}}$ & $55.76^{\mathrm{b}}$ \\
Viability (\%) & 90.50 & 91.16 & 90.73 & 89.67 & 89.78 & 91.01 & 89.60 \\
\hline
\end{tabular}

${ }^{a-d}$ Means in the same row with different superscripts are significantly $(p<0.05)$ different.

Treatments are $\%$ watermelon in dextrose saline diluents: T1 is undiluted semen (positive control); T2, 10\%; T3, 20\%; T4, 30\%; T5, 40\%; T6, 50\%; T7, 0\%. 
motility of undiluted semen (T1) was not significantly $(p>0.05)$ different from the diluted semen groups. The percentage motility was significantly $(p<0.05)$ highest in T2 and the significantly $(p<$ 0.05 ) lowest values is obtained in T7. Progressive motility of semen in T1, T3, and T4 are not significantly $(p>0.05)$ different but were significantly $(p<0.05)$ higher than T2. Similarly, non-progressive motility of semen on T2 was significantly $(p<0.05)$ higher than semen on T1, T3, T4, and T5. Curvilinear velocity, average path velocity and viability of the extended semen were not significantly $(p>0.05)$ affected by the treatments. Straight line velocity of semen on T2 was significantly $(p<0.05)$ higher than semen on T4. Linearity of semen on T2 was significantly $(p<0.05)$ higher than T6, while semen linearity values for T1, T3, T4, and T5 had the significantly $(p<0.05)$ lowest values. Straightness of semen across the treatment was significantly $(p<0.05)$ highest in T2 and T7 and values for T1 and T3 was significantly $(p<0.05)$ lowest. Amplitude of lateral head in semen on T6 was significantly $(p<0.05)$ higher than those on T2. And the significantly $(p<0.05)$ lowest values were found in T3 and T5. Beat cross frequency was statistically similar in T1 and T5 and were significantly $(p<0.05)$ higher than T7. Wobble of semen on T1 and T5 was significantly $(p<0.05)$ lower than T7 and the significantly $(p<0.05)$ highest value was obtained in semen on T2.

\section{Semen quality of watermelon extended rooster semen for 2 hours}

Semen quality of watermelon extended rooster semen for 2 hours is shown in Table 3. Percentage motility in undiluted semen is not significantly $(p>0.05)$ different from the extended semen groups (T2-T7). Progressive motility of semen in T1, T2, T3, T5, and T6 were not significantly $(p>0.05)$ different but were significantly $(p<0.05)$ higher than semen on T7 and T4. Non progressive motility of semen in T4 and T7 were significantly higher than other semen treatment groups. Curvilinear velocity of semen in T4 was significantly $(p<0.05)$ highest and the significantly $(p<0.05)$ lowest was observed T2. Average path velocity in semen on T4 was significantly $(p<0.05)$ highest across the treatment, undiluted semen samples had statistically similar values as diluted semen samples in T5 and T7. Straight line velocity of undiluted semen samples was not significantly $(p>0.05)$ different from semen in T2, T3, T5, and T6 and were significantly $(p<0.05)$ higher than semen obtained in T7, while the significantly $(p<0.05)$ highest values were obtained in T4. Linearity of undiluted semen is not significantly $(p>0.05)$ different from semen In T2, T3, T5, and T6 but were signifi-

Table 3. Semen characteristics of watermelon extended rooster semen at 2 hour

\begin{tabular}{|c|c|c|c|c|c|c|c|}
\hline Parameters & T1 & T2 & T3 & T4 & T5 & T6 & $\mathrm{T7}$ \\
\hline Percentage motility (\%) & $89.97^{\mathrm{ab}}$ & $90.30^{\mathrm{ab}}$ & $89.53^{\mathrm{ab}}$ & $89.89^{\mathrm{ab}}$ & $90.74^{a}$ & $89.23^{b}$ & $89.72^{\mathrm{ab}}$ \\
\hline Progressive motility (\%) & $83.66^{a}$ & $85.22^{\mathrm{a}}$ & $83.70^{\mathrm{a}}$ & $75.50^{\mathrm{b}}$ & $83.62^{\mathrm{a}}$ & $83.83^{\mathrm{a}}$ & $77.84^{\mathrm{b}}$ \\
\hline Non- progressive motility (\%) & $6.31^{\mathrm{b}}$ & $5.09^{b}$ & $5.83^{b}$ & $14.39^{\mathrm{a}}$ & $7.12^{\mathrm{b}}$ & $5.40^{\mathrm{b}}$ & $11.87^{\mathrm{a}}$ \\
\hline Curvilinear velocity $(\mathrm{VCL})(\mu \mathrm{m} / \mathrm{s})$ & $18.52^{b}$ & $17.61^{\mathrm{c}}$ & $18.14^{b}$ & $19.94^{\mathrm{a}}$ & $18.18^{b}$ & $18.25^{\mathrm{b}}$ & $18.48^{\mathrm{b}}$ \\
\hline Average path velocity $(\mathrm{VAP})(\mu \mathrm{m} / \mathrm{s})$ & $10.05^{\mathrm{bc}}$ & $9.47^{\mathrm{e}}$ & $9.67^{d}$ & $11.25^{\mathrm{a}}$ & $9.82^{\mathrm{c}}$ & $9.65^{d}$ & $10.34^{\mathrm{b}}$ \\
\hline Straight line velocity (VSL) ( $\mu \mathrm{m} / \mathrm{s})$ & $4.15^{\mathrm{c}}$ & $3.98^{\mathrm{c}}$ & $4.06^{\mathrm{c}}$ & $4.85^{\mathrm{a}}$ & $4.18^{\mathrm{c}}$ & $3.97^{\mathrm{c}}$ & $4.48^{\mathrm{b}}$ \\
\hline Linearity (\%) & $22.38^{\mathrm{bc}}$ & $22.61^{\mathrm{bc}}$ & $22.35^{\mathrm{bc}}$ & $24.39^{\mathrm{a}}$ & $22.99^{b}$ & $21.74^{\mathrm{c}}$ & $24.21^{a}$ \\
\hline Straightness (\%) & $41.25^{\mathrm{c}}$ & $42.04^{\mathrm{bc}}$ & $41.95^{\mathrm{bc}}$ & $43.15^{\mathrm{a}}$ & $42.55^{\mathrm{ab}}$ & $41.09^{c}$ & $43.27^{\mathrm{a}}$ \\
\hline Amplitude of lateral head (ALH) $(\mu \mathrm{m})$ & $0.50^{\mathrm{b}}$ & $0.50^{\mathrm{bc}}$ & $0.49^{c}$ & $0.55^{\mathrm{a}}$ & $0.49^{c}$ & $0.50^{\mathrm{bc}}$ & $0.50^{b}$ \\
\hline Beat cross frequency $(\mathrm{BCF})(\mathrm{Hz})$ & $4.71^{\mathrm{a}}$ & $4.44^{\mathrm{b}}$ & $4.57^{\mathrm{ab}}$ & $4.75^{\mathrm{a}}$ & $4.61^{\mathrm{ab}}$ & $4.68^{\mathrm{a}}$ & $4.43^{b}$ \\
\hline Wobble (\%) & $54.25^{\mathrm{b}}$ & $53.77^{b}$ & $53.29^{b}$ & $56.39^{\mathrm{a}}$ & $54.03^{b}$ & $52.88^{b}$ & $56.94^{\mathrm{a}}$ \\
\hline Viability (\%) & 89.97 & 90.30 & 89.53 & 89.89 & 90.74 & 89.23 & 89.72 \\
\hline
\end{tabular}

${ }^{\mathrm{a}-\mathrm{e}}$ Means in the same row with different superscripts are significantly $(p<0.05)$ different.

Treatments are $\%$ watermelon in dextrose saline diluents: T1 is undiluted semen (positive control); T2, 10\%; T3, 20\%; T4, 30\%; $\mathrm{T} 5,40 \%$; T6, 50\%; T7, 0\%. 
cantly $(p<0.05)$ lower than semen samples in T4 and T7. Straightness of undiluted samples were significantly $(p>0.05)$ similar with samples in T2, T3, and T6 but were significantly $(p<0.05)$ lower than semen in T4, T5, and T7. Semen samples in T4 had the significantly $(p<0.05)$ highest amplitude of lateral head while the significantly $(p<0.05)$ lowest values is obtained in semen in T3 and T5. Beat cross frequency of undiluted semen was not significantly $(p>0.05)$ different from semen samples in T3, T4, T5, and T6, but were significantly $(p<0.05)$ higher than semen on T2 and T7. The wobble in semen on T4 and T7 was significantly $(p<0.05)$ higher than semen on T1, T2, $\mathrm{T} 3, \mathrm{~T} 5$, and T6. The viability of semen across the treatments were not significantly $(p>0.05)$ different.

\section{Semen quality of watermelon extended rooster semen for 3 hours}

Semen quality of watermelon extended rooster semen for 3 hours is shown in Table 4 . The percentage motility of undiluted semen was not significantly $(p>0.05)$ different from watermelon fortified semen (T2, T3, T4, T5, and T6) and were significantly $(p<0.05)$ higher than semen diluted with only dextrose saline (T7). Progressive motility of undiluted semen was significantly $(p>0.05)$ similar with semen in T2 and were significantly $(p<0.05)$ higher than semen in T3, T4, T6, and T7, while significantly $(p<0.05)$ lowest values was obtained in T5.

Non-progressive motility of semen samples in T5 was significantly $(p<0.05)$ highest and the lowest values was obtained in T2. Curvilinear velocity of semen samples in T4 and T5 were significantly $(p<0.05)$ highest and significantly $(p<0.05)$ lowest value was obtained in semen on T7. Average path velocity and straight line velocity of undiluted semen is not significantly $(p>0.05)$ different from T2 and T7 wand were significantly $(p<0.05)$ higher than T3, T4, and T6. Linearity, wobble and Straightness of semen diluted with only dextrose saline was significantly $(p<0.05)$ higher than undiluted semen and watermelon fortified semen groups. Amplitude of lateral head of semen diluted with dextrose saline was significantly $(p<0.05)$ lowest and the significantly $(p<0.05)$ highest values was obtained in semen on $\mathrm{T} 5$.

\section{Oxidative status and fertility assessment of watermelon extended rooster semen}

The antioxidant activity of seminal plasma declines across all the treatment groups with time from zero hours to 5 hours (Fig. 1). At zero hour, as watermelon inclusion in semen increased it led to

Table 4. Semen characteristics of watermelon extended rooster semen at 3 hour

\begin{tabular}{|c|c|c|c|c|c|c|c|}
\hline Parameters & T1 & T2 & T3 & T4 & T5 & T6 & $\mathrm{T7}$ \\
\hline Percentage motility (\%) & $90.37^{a}$ & $90.02^{a}$ & $91.47^{\mathrm{a}}$ & $91.99^{a}$ & $92.84^{a}$ & $90.99^{a}$ & $80.74^{b}$ \\
\hline Progressive motility (\%) & $80.66^{\mathrm{a}}$ & $83.55^{\mathrm{a}}$ & $66.08^{\mathrm{b}}$ & $62.99^{b}$ & $46.70^{\mathrm{c}}$ & $68.51^{b}$ & $61.36^{b}$ \\
\hline Non- progressive motility (\%) & $9.71^{\mathrm{C}}$ & $6.47^{d}$ & $25.41^{b}$ & $29.00^{b}$ & $46.15^{\mathrm{a}}$ & $22.49^{b}$ & $19.37^{\mathrm{ab}}$ \\
\hline Curvilinear velocity $(\mathrm{VCL})(\mu \mathrm{m} / \mathrm{s})$ & $18.20^{\mathrm{c}}$ & $17.79^{c}$ & $20.89^{b}$ & $26.68^{\mathrm{a}}$ & $26.96^{\mathrm{a}}$ & $23.24^{\mathrm{b}}$ & $10.19^{d}$ \\
\hline Average path velocity (VAP) $(\mu \mathrm{m} / \mathrm{s})$ & $10.11^{c}$ & $9.65^{c}$ & $13.51^{b}$ & $14.88^{b}$ & $18.13^{\mathrm{a}}$ & $13.04^{b}$ & $8.98^{c}$ \\
\hline Straight line velocity (VSL) ( $\mu \mathrm{m} / \mathrm{s})$ & $4.31^{\mathrm{c}}$ & $4.07^{\mathrm{C}}$ & $6.51^{b}$ & $6.44^{b}$ & $8.41^{\mathrm{a}}$ & $5.81^{\mathrm{b}}$ & $5.42^{\mathrm{c}}$ \\
\hline Linearity (\%) & $23.69^{c}$ & $22.88^{\mathrm{c}}$ & $30.94^{b}$ & $24.14^{c}$ & $35.76^{b}$ & $24.98^{c}$ & $58.03^{\mathrm{a}}$ \\
\hline Straightness (\%) & $42.60^{\mathrm{bc}}$ & $42.22^{\mathrm{bc}}$ & $47.31^{b}$ & $43.27^{b c}$ & $38.99^{c}$ & $44.54^{b}$ & $60.12^{\mathrm{a}}$ \\
\hline Amplitude of lateral head (ALH) $(\mu \mathrm{m})$ & $0.57^{d}$ & $0.49^{d}$ & $0.66^{c}$ & $0.73^{b}$ & $0.84^{\mathrm{a}}$ & $0.65^{\mathrm{c}}$ & $0.39^{\mathrm{e}}$ \\
\hline Beat cross frequency (BCF) (Hz) & $4.28^{\mathrm{bc}}$ & $4.61^{\mathrm{bc}}$ & $3.94^{\mathrm{c}}$ & $5.54^{\mathrm{a}}$ & $4.44^{\mathrm{bc}}$ & $5.05^{\mathrm{ab}}$ & $1.46^{\mathrm{d}}$ \\
\hline Wobble (\%) & $55.59^{c}$ & $54.20^{c}$ & $64.41^{b}$ & $55.78^{c}$ & $67.42^{b}$ & $56.13^{c}$ & $88.33^{a}$ \\
\hline Viability (\%) & 90.37 & 90.02 & 91.47 & 91.99 & 92.84 & 90.99 & 80.74 \\
\hline
\end{tabular}




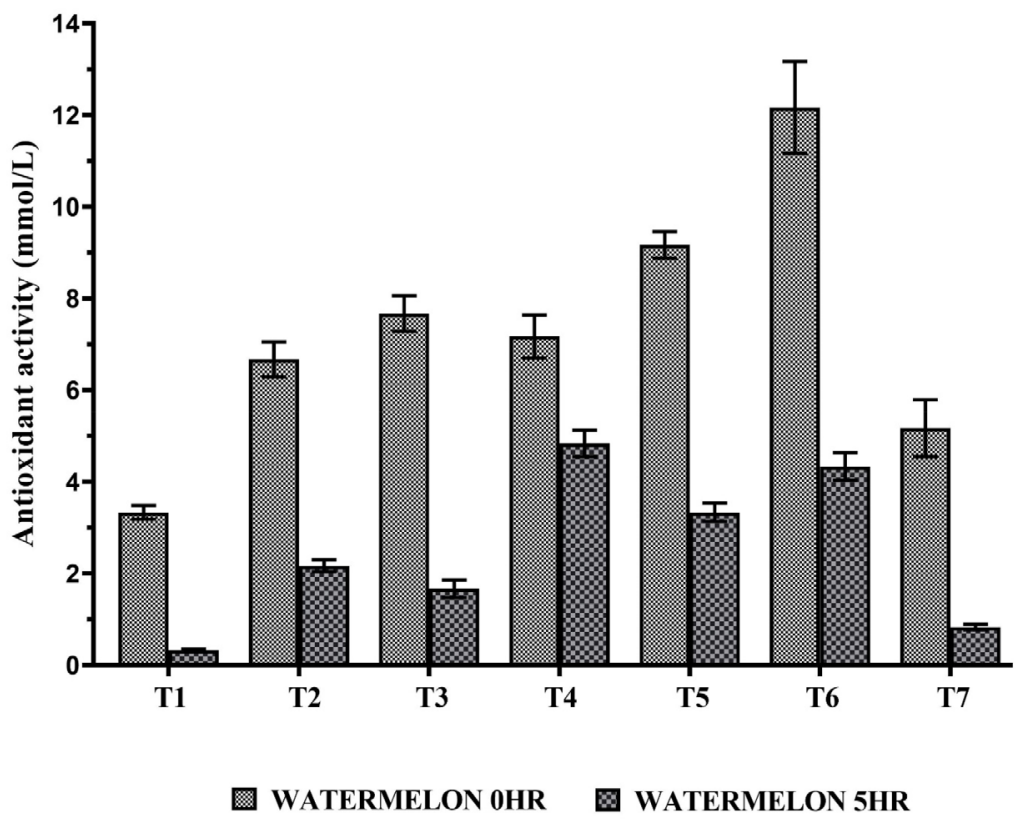

Fig. 1. Antioxidant activity of rooster semen in watermelon-dextrose based diluent. Treatments are $\%$ watermelon in dextrose saline diluents: T1 is undiluted semen (positive control); T2, 10\%; T3, 20\%; T4, 30\%; T5, $40 \% ; \mathrm{T} 6,50 \% ; \mathrm{T} 7,0 \%$ (negative control).

corresponding increase in seminal antioxidant activity. The lowest values were found in undiluted semen and dextrose saline diluted semen groups. Lipid peroxidation of seminal of undiluted semen and dextrose saline diluted groups increase from 0 hours to 5 hours (Fig. 2). This is contrary to the rate of lipid peroxidation in watermelon-dextrose diluted semen, which declined from 0 hours to 5 hours. The fertility of hens inseminated with watermelon extended semen is shown in Fig. 3. The percentage fertility was highest in T3 (81.01\%) and T4 (81.24\%) with lowest value obtained in T7 (73.46\%). Hatchability of eggs set of hens inseminated with undiluted semen (71.46\%) was lower than values for hens inseminated with watermelon inclusive extended semen (75.71\%-80.39\%). The hatchability of fertile eggs was highest in hens inseminated with T4 (99.07\%) and the lowest values was obtained in hens inseminated with T7 (94.8).

\section{DISCUSSION}

Seminal plasma has limited antioxidant capacity, thus the need for an extender with strong antioxidant effect to maintain the viability and subsequent fertilizing capacity. This study elucidated the importance of watermelon in enhancing viability of rooster semen. From in vitro results watermelon in dextrose saline in semen dilution enhanced progressive motility and low non progressive motility, this is in congruent with a recent study that showed WMJ as a potent semen diluent [13]. Although, Adebisi and Ewuola [17] documented the potency of dextrose saline as a superior semen diluent in poultry. The higher performance of watermelon fortified semen can be attributed to the phytoconstituents of watermelon chiefly, antioxidants such as vitamin $\mathrm{C}$, lycopene and beta carotene. Consequently, study have stated that the addition of vitamin $\mathrm{C}$ to an extender could possibly improve sperm function by reducing cell damage through its continuous radical-scavenging action [18]. For instance, alpha-tocopherol which is one of the main antioxidants, was found to be abundant in spermatozoa membrane that protects sperm from oxidative damage [19]. Similarly, 


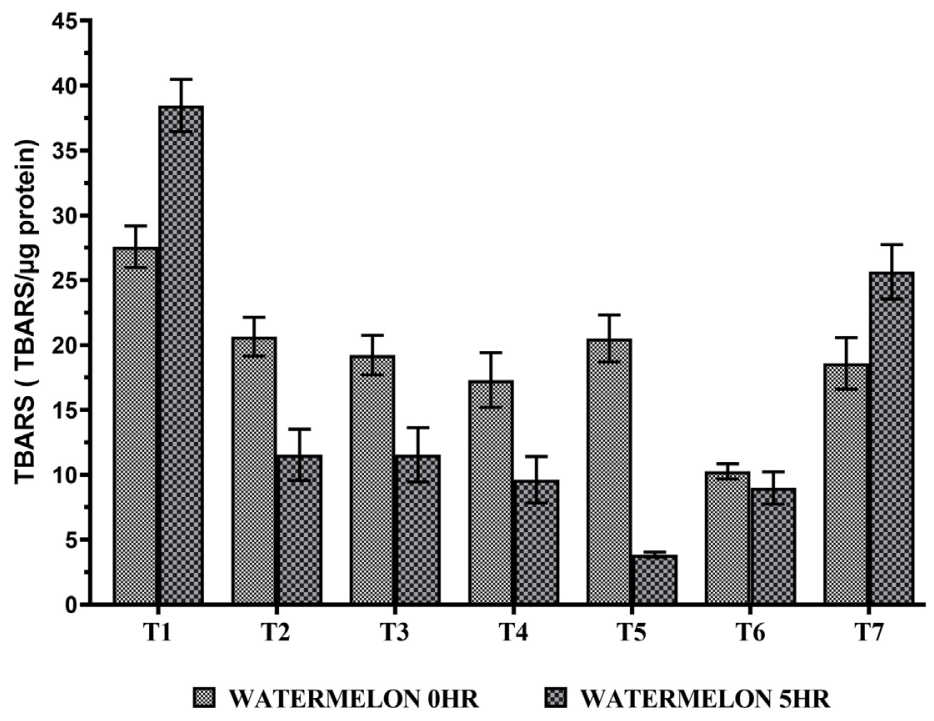

Fig. 2. Lipid peroxidation of rooster semen in watermelon-dextrose based diluent. Treatments are $\%$ watermelon in dextrose saline diluents: T1 is undiluted semen (positive control); T2, 10\%; T3, 20\%; T4, 30\%; T5, $40 \% ; \mathrm{T} 6,50 \% ; \mathrm{T} 7,0 \%$ (negative control).

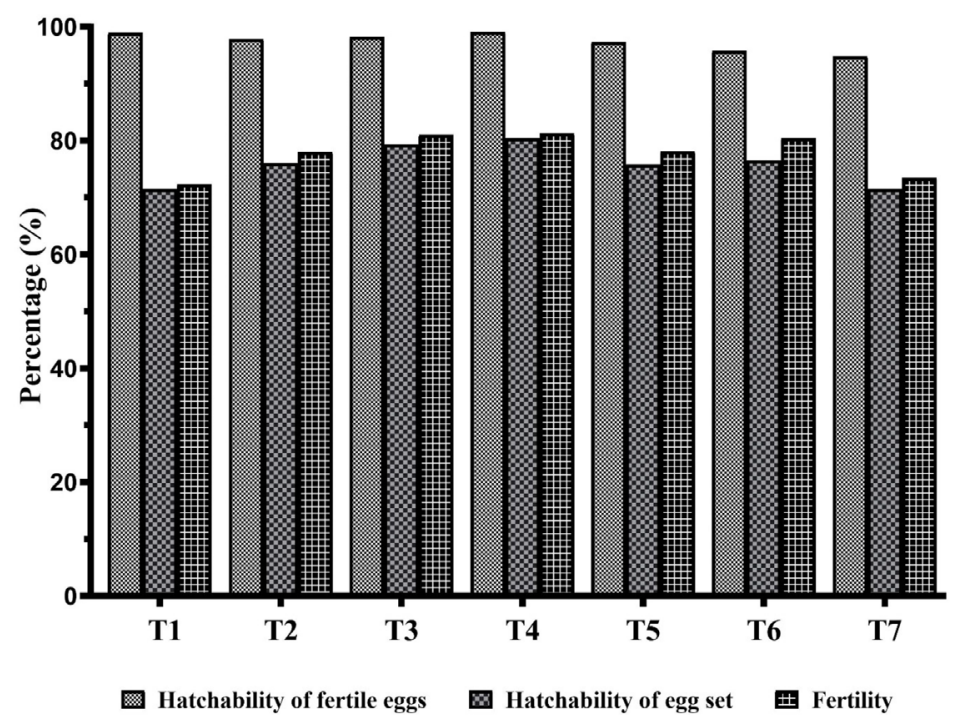

Fig. 3. Fertility of hens inseminated with watermelon-dextrose extended rooster semen. Treatments are $\%$ watermelon in dextrose saline diluents: T1 is undiluted semen (positive control); T2, 10\%; T3, 20\%; T4, 30\%; $\mathrm{T} 5,40 \% ; \mathrm{T} 6,50 \% ; \mathrm{T} 7,0 \%$ (negative control).

lycopene in tomato juice acts as an antioxidant that protect spermatozoa from oxidative damage in an extender composition [1]. Tvrda et al. [20] suggested that lycopene supplementation to semen extender acts as an effective motion-promoting and membrane protecting molecule, by significantly improving spermatozoa motility, membrane integrity, and mitochondrial activity during preservation. The results shows that watermelon addition to rooster semen diluent enhance the antioxidant prowess of rooster semen and lower lipid peroxide generation. This shows that watermelon inclusion in dextrose enhance scavenging ability of the ROS and free radical and consequently reduced lipid peroxidation in rooster semen. This would account for the trend in semen kinetics and motility 
in this study. Amedu \& Idoko [21] also reported that watermelon (Citrullus lanatus) promotes normal sperm morphology, concentration, motility and volume of rat semen. C. lanatus thus possess health benefits as it contains lycopene with rich antioxidant. The inclusion of watermelon in rooster semen performed better than undiluted semen despite over 3 hours storage, this is similar to results from Mangiagalli et al. [22] that reported positive effects of lycopene supplementation to extender on fowl sperm survival during liquid storage. Report that vitamin $\mathrm{C}$ is naturally present in seminal plasma to scavenge and decrease numerous disruptive free radical processes, including lipid peroxidation [23], show the enhancement potential of watermelon bound antioxidant complex in enhancing semen quality of rooster semen. Thus sperm kinetics properties of extended semen tend to be better with watermelon inclusion. This is similar to claims of Zheng \& Zhang [24] that antioxidative compounds are beneficial for sperm viability and reduction of lipid peroxidative damage to sperm membranes.

In vivo result showed that watermelon in dextrose saline when used as diluent for rooster semen enhanced fertility and hatchability of eggs than undiluted semen and dextrose saline. This thus corroborates claim by Jimoh \& Ayedun [13] that WMJ is a potent diluent and can be incorporated as extender constituent in the preservation of semen for optimal performance. Finally, watermelon based diluents enhance reproductive output of animals in assisted reproductive techniques which is in line with report of Mangiagalli et al. [25] that lycopene addition affects reproductive performance of multiparous rabbit does inseminated with fresh semen.

\section{CONCLUSION}

The supplementation of watermelon in dextrose saline as rooster semen diluent revealed its potential to enhance spermatozoa motility and sperm kinetics over 3 hours of observation. The hatchability and fertility of eggs obtained from hens inseminated with watermelon-dextrose saline diluted semen were better than only dextrose diluted semen. The optimal inclusion of 30\%-50\% watermelon in dextrose saline diluent enhance semen kinetics, fertility and hatchability of eggs obtained from inseminated hens and were better than result obtained with undiluted semen. It can be recommended that future efforts should focus on natural/organic products in extender composition to cryopreserve rooster semen to utilize the potentials of watermelon revealed in this study.

\section{REFERENCES}

1. Esguerra JPM, Quimio JMUPH, Dichoso GA, Junsay CAL, Magpantay VA, Sangel PP. Coconut water with either tomato juice or garlic extract as extender components for Paraoakan native chicken semen at different storage temperatures. Philipp J Sci. 2020;149:121-31.

2. Aji R, Agus A, Widyobroto BP, Hartatik T, Budisatria GS, Fathoni A, et al. The effect of Andromed $^{\circledR}$ and coconut water+ $20 \%$ egg yolk as diluent on semen motility of Belgian Blue cattle. IOP Conf Ser Earth and Environ Sci. 2019;387:012127.

3. Jimoh OA. Assessment of the oxidative stress markers and reproductive performance of four exotic breeds of rabbit in Ibadan [Ph.D. dissertation]. Ibadan, Nigeria: University of Ibadan; 2016. p. 48. https://doi.org/10.13140/RG.2.2.27229.23522/1

4. Jimoh OA, Ewuola EO. Semen characteristics, seminal biochemical and oxidative stress markers in rabbits during heat stress. J Vet Androl. 2018;3:35-44.

5. Jimoh OA, Ihejirika UG, Balogun AS, Uwaeziozi UC. Antioxidative effect of mistletoe leaf meal supplemented diets in laying pullets. Arch de Zootec. 2018;67:526-30. https://doi. org/10.21071/az.v0i0.3883 
6. Jimoh OA, Ayedun ES, Oyelade WA, Oloruntola OD, Daramola OT, Ayodele SO, et al. Protective effect of soursop (Annona muricata Linn.) juice on oxidative stress in heat stressed rabbits.J Anim Sci Technol. 2018;60. https://doi.org/10.1186/s40781-018-0186-4

7. Jimoh OA, Ihejirika UG, Balogun AS, Adelani SA, Okanlawon OO. Antioxidant status and serology of laying pullets fed diets supplemented with mistletoe leaf meal. Niger J Anim Sci. 2018;20:52-60.

8. Bayemi PH, Banla NR, Leinyuy I, Niba AT, Nsongka VM, Mario G, et al. Use of fruits and raffia palm sap (Raffia hookeri) in chilled bull semen extenders in Cameroon. Agric Biol Sci J. 2015;1:142-9.

9. Balogun A, Jimoh O. Efficacy of egg-yolk citrate extender fortified with aqueous garlic extract on rooster semen for artificial insemination. Niger J Anim Sci. 2017;19:62-70.

10. El-Sheshtawy RI, El-Nattat WS, Ali GAD. Cryopreservation of cattle semen using coconut water extender with different glycerol concentrations. Asian Pac J Reprod. 2017;6:279-82. https://doi.org/10.4103/2305-0500.217343

11. Khaki A, Fathiazad F, Nouri M. Effects of watermelon seed extract (Citrullus vulgaris) on spermatogenesis in rat. Int J Women's Health Reprod Sci. 2013;1:99-104. https://doi. org/10.15296/ijwhr.2013.16

12. Kolawole T, Adienbo O, Dapper V. Ameliorative effects of hydromethanolic extract of Citrullus lanatus (watermelon) rind on semen parameters, reproductive hormones and testicular oxidative status following nicotine administration in male Wistar rats. Niger J Physiol Sci. 2019;34:8390.

13. Jimoh OA, Ayedun ES. Calidad y fertilidad del semen de conejo diluido con jugo de sandía. Arch de zootec. 2020;69:140-6. https://doi.org/10.21071/az.v69i266.5108

14. Balogun A, Jimoh O, Mustapha T, Olapoju G, Ojo J. Comparative semen characteristics of Nigeria indigenous cock and exotic strains of domestic fowl. Niger J Anim Sci. 2015;17:148-53.

15. Ohkawa $\mathrm{H}$, Ohishi N, Yagi K. Assay for lipid peroxides in animal tissues by thiobarbituric acid reaction. Anal Biochem. 1979;95:351-8. https://doi.org/10.1016/0003-2697(79)90738-3

16. Koracevic D, Koracevic G, Djordjevic V, Andrejevic S, Cosic V. Method for the measurement of antioxidant activity in human fluids. J Clin Pathol. 2001;54:356-61. https://doi.org/10.1136/ jcp.54.5.356

17. Adebisi K, Ewuola E. Comparative effect of saline solutions as diluents on in vitro semen storage, egg fertility and hatchability in Turkey hens. Niger J Anim Sci. 2019;21:107-16.

18. Adekunle EO, Daramola JO, Sowande OS, Abiona JA, Abioja MO. Effects of apple and orange juices on quality of refrigerated goat semen. J Agric Sci (Belgrade). 2018;63:53-65. https://doi.org/10.2298/JAS1801053A

19. El-Sheshtawy RI, El-Sisy GA, El-Nattat WS. Effects of pomegranate juice in tris-based extender on cattle semen quality after chilling and cryopreservation. Asian Pac J Reprod. 2016;5:335-9. https://doi.org/10.1016/j.apjr.2016.06.001

20. Tvrda E, Mackovich A, Greifova H, Hashim F, Lukac N. Antioxidant effects of lycopene on bovine sperm survival and oxidative profile following cryopreservation. Vet Med. 2017;62:42936. https://doi.org/10.17221/86/2017-VETMED

21. Amedu NO, Idoko UP. Dietary consumption of citrullus lanatus can ameliorate infertility potential of carica papaya seeds extract in male rats. Biotechnol J Int. 2016;11:1-9. https://doi. org/10.9734/BBJ/2016/22805

22. Mangiagalli MG, Marelli SP, Cavalchini LG. Effect of lycopene on fowl sperm characteristics during in vitro storage. Archiv für Geflügelkunde. 2007;71:25-9.

23. Gangwar C, Kharche SD, Ranjan R, Kumar S, Goel AK, Jindal SK, et al. Effect of vitamin C 
supplementation on freezability of Barbari buck semen. Small Rumin Res. 2015;129:104-7. https://doi.org/10.1016/j.smallrumres.2015.06.002

24. Zheng RL, Zhang H. Effects of ferulic acid on fertile and asthenozoospermic infertile human sperm motility, viability, lipid peroxidation, and cyclic nucleotides. Free Radic Biol Med. 1997;22:581-6. https://doi.org/10.1016/S0891-5849(96)00272-9

25. Mangiagalli MG, Cesari V, Cerolini S, Luzi F, Toschi I. Effect of lycopene supplementation on semen quality and reproductive performance in rabbit. World Rabbit Sci. 2012;20:141-8. https://doi.org/10.4995/wrs.2012.1150 